\title{
A methodology for combining multiple commercial data sources to improve measurement of the food and alcohol environment: applications of geographical information systems
}

\author{
Dara D. Mendez ${ }^{1}$, Jessica Duell ${ }^{1}$, Sarah Reiser ${ }^{1}$, Deborah Martin ${ }^{1}$, Robert Gradeck ${ }^{2}$, Anthony \\ Fabio $^{1}$ \\ ${ }^{1}$ University of Pittsburgh, Graduate School of Public Health, Department of Epidemiology, Pittsburgh, USA; \\ ${ }^{2}$ University of Pittsburgh, Center for Social and Urban Research, Pittsburgh, USA
}

\begin{abstract}
Commercial data sources have been increasingly used to measure and locate community resources. We describe a methodology for combining and comparing the differences in commercial data of the food and alcohol environment. We used commercial data from two commercial databases (InfoUSA and Dun\&Bradstreet) for 2003 and 2009 to obtain information on food and alcohol establishments and developed a matching process using computer algorithms and manual review by applying ArcGIS to geocode addresses, standard industrial classification and North American industry classification taxonomy for type of establishment and establishment name. We constructed population and area-based density measures (e.g. grocery stores) and assessed differences across data sources and used ArcGIS to map the densities. The matching process resulted in 8,705 and 7,078 unique establishments for 2003 and 2009, respectively. There were more establishments captured in the combined dataset than relying on one data source alone, and the additional establishments captured ranged from 1,255 to 2,752 in 2009 . The correlations for the density measures between the two data sources was highest for alcohol outlets $(\mathrm{r}=0.75$ and 0.79 for per capita and area, respectively) and lowest for grocery stores/supermarkets $(\mathrm{r}=0.32$ for both). This process for applying geographical information systems to combine multiple commercial data sources and develop measures of the food and alcohol environment captured more establishments than relying on one data source alone. This replicable methodology was found to be useful for understanding the food and alcohol environment when local or public data are limited.
\end{abstract}

Keywords: food and alcohol establishments, neighbourhood, geocoding, geographical information systems, database, USA.

\section{Introduction}

Resources within community and neighbourhood contexts such as grocery stores or the placement of liquor stores may provide insight into important public health issues such as weight gain, obesity, violence and health behaviours including diet and alcohol use (Feng et al., 2010; Janevic et al., 2010; Ahern et al., 2013; Shimotsu et al., 2013). However, there are no consistent publicly-available sources of data on businesses such as food and alcohol establishments in the United States of America (USA). Public data that could be used for these purposes are often inaccessible or unavailable in a standardised format. As a result, there has been growing interest in commercial data for measuring and operationalising neighbourhood

\footnotetext{
Corresponding author:

Dara D. Mendez

University of Pittsburgh

Graduate School of Public Health, Department of Epidemiology

Crabtree Hall, A716, Pittsburgh, PA 15261, USA

Tel. +1 412-648-5664; Fax +1 412-642-7397

E-mail: ddm11@pitt.edu
}

resource environments (Ohri-Vachaspati et al., 2011; Gustafson et al., 2012a, 2012b).

In applying business and commercial databases, researchers have cited limitations including inadequate numeration of establishments, differences in accuracy of establishment locations, differences in business classifications (e.g. fast food places versus regular restaurant or wholesale versus retail grocery), and variation in completeness of business information by neighbourhood demographics (e.g. racial composition, urban/rural location) (Liese et al., 2010; OhriVachaspati et al., 2011; Han et al., 2012). However, these data sources may be an efficient and cost-effective method for enumerating establishments and characterising neighbourhood environments. Prior studies cite the benefit of using more than one business database when measuring the neighbourhood food environment and perhaps other related neighbourhood and community resources (Liese et al., 2010). However, we are not aware of any studies that discuss a methodology or process for combining multiple commercial data sources for applications in public health research. 
The purpose of this study was to find and describe the process for combining commercial data to construct a geocoded, multisource database of the neighbourhood food and alcohol environment. We present here key issues to consider when using multiple commercial data sources for applications in public health research. We then assess the differences in density measures (e.g. density of grocery stores) between the individual data sources and the merged database.

\section{Methods}

\section{Data sources}

We used two commercial databases, InfoUSA (http://www.infousa.com/) and Dun\&Bradstreet (D\&B) (http://www.dnb.com/), based on data generated in 2009 and 2003 for Allegheny county, PA as a part a larger study investigating the relationship between neighbourhood food and alcohol environments and health. InfoUSA and D\&B are sales and marketing companies that provide data of businesses in the USA and Canada. Both companies compile data through a combination of methods including telephone directories, public records and internet searchers, and the use of teleconference associates. Each data source contains information about the name, address and type of establishment. Types of establishments and associated classifications are based on standard industrial classification (SIC) and North American industry classification (NAICS) taxonomy. We also used the 2000 US Census population and demographic data including the number of residents per census tract and the area in square miles for each census tract in Allegheny county to calculate density measures (e.g. density of grocery stores within a geographic region).

\section{Geocoding}

We geocoded all establishments since longitude and latitude were not provided for all establishments. The reference database used to geocode establishments, which could influence the quality of our geocoding (Karimi et al., 2004), was based on local data provided by the Allegheny county GIS department. The local, reference database included a combination of street and rooftop, which produces higher match rates and positional accuracy (Roongpiboonsopit and Karimi, 2010). We used ArcGIS, version 10 (ESRI, Redlands, USA) to geocode establishments. Spelling sensitivity was set at 70 , minimum candidate score at 10 and minimum match score at 60 . The settings were chosen based on a review of business locations listed in the dataset; they provided the best matches with the fewest false positive matches. Ties were automatically assigned the first matched address, and we performed no manual matching to minimise subjectivity. Output included XY coordinates, which were spatially matched to census tracts using year 2000 government census shapefiles. For the 2003 data, we were able to successfully geocode $87.2 \% \quad(\mathrm{n}=6,849 ; 1,008$ were unmatched to address points in the geocoding reference file) of the establishments from and $83.1 \%$ $(\mathrm{n}=3,316 ; 672$ were unmatched) for InfoUSA. For data from 2009, we were able to successfully geocode $86.1 \%(\mathrm{n}=5,073 ; 817$ were unmatched) of the D\&B establishments and $84.9 \%(\mathrm{n}=3,679 ; 656$ were unmatched) from InfoUSA. Based on prior work, our address match rates were optimal based on street and rooftop source files produced by the same agency (Roongpiboonsopit and Karimi, 2010).

\section{The establishment matching process}

To combine the datasets, it was necessary to first identify establishments that existed across InfoUSA and D\&B. We developed an algorithm for use in SAS (SAS Institute Inc, Cary, USA) to automate the process. Our study team conducted an extensive process to match and cross-reference food and alcohol establishments across the InfoUSA and D\&B datasets (see Fig. 1). We identified four items that consistently existed on the records in both databases: name or trade name of the business, address, phone number, and SIC code. Location match or an XY (longitude, latitude) match between the two sources was the first match test. However, a location match did not guarantee that the establishments were the same business. For example, relocation, obsolete sources data or a shopping centre with several establishments could result in an invalid match. Therefore, the programme conducted a name/trade name, phone number and SIC code comparison.

The computer name matching involved multiple levels. First, we applied a spelling distance algorithm to account for data entry errors. When establishment names did not match based on spelling distance, the programme matched them based on the number of words that were identical to account for different order of words in the establishment names in the two databases. Abbreviations used in the commercial database also prevented a programme match that was obvious when reviewed by study personnel. The study team also compiled a list of key words that when 


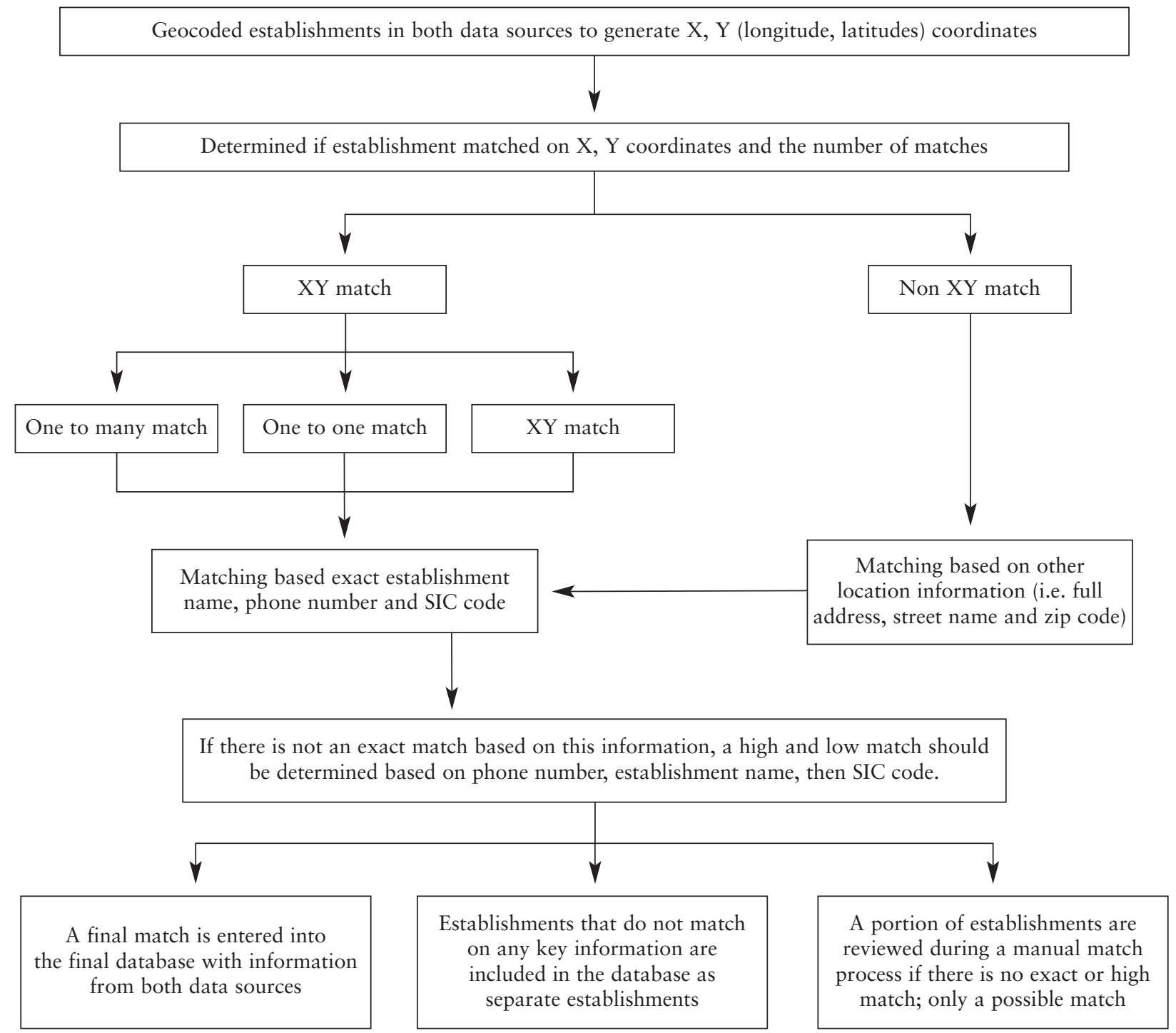

Fig. 1. Decision tree of key elements for building database and matching establishments.

found in both databases names, automatically matched the establishments to account for establishments that contained these keywords but otherwise did not match per the matching algorithm (e.g. state liquor stores had "LIQUOR" in the business name in both data sources). Any establishments that were not a definitive match based on XY coordinates, name, phone number and SIC through the computer programme were reviewed by 2-3 study personnel. A consensus on the matching status of each establishment was determined. For these establishments, additional variables were used during the review (e.g. CEO name, secondary and tertiary SIC and NAICS codes). Records that did not match across the two datasets based on XY coordinates were further examined for a match. Location match of these establishments was based on a street name, zip code, house number and the unit number if applicable. If the establishments matched (non-XY) on all characteristics and were on the same street, we reviewed them to ensure there were not two locations of the same chain (e.g. chain grocery store) on the same street. We also reviewed establishments that matched on two or more characteristics (e.g. phone number and name, same street and name, same street and phone number). In some cases, the address in one data source did not match the address in the other data source because of incorrect information (e.g. wrong/missing zip code, E(ast) instead of W(est), Old was missing). Finally, all matches were included in one database. 


\section{Measures and analysis}

We operationalised the neighbourhood environment at the level of the census tract using US Census boundaries for the year 2000. Although other neighbourhood units were considered, prior work indicates census tracts as viable neighbourhood units of measuring the neighbourhood food and alcohol environment and may be best when calculating per capita and area density measures (Liese et al., 2010; Shier et al., 2012). First, various establishments were categorised according to SIC codes. The Supplement Table A includes a full listing of codes and how establishments were grouped. There were some differences in how establishments were categorised across datasets and both datasets included primary, secondary and sometimes tertiary SIC codes. Some examples are included in the Supplement, Table B. To account for differences in establishment classification, we created density measures based on primary SIC code and any SIC code (e.g. primary, secondary or tertiary). Establishments could be categorised in several different grouping, depending on the type of establishment. For example, restaurants serving alcohol could be categorised as an alcohol outlet and a restaurant.

We also created census-tract level density measures by summing the number of establishments within each census tract for each category and dividing based on per capita (per 10,000 residents) and per area (square mile) from population and area data generated from the US census. The key density measures presented in the results include on premise (i.e. bars and restaurants) and off premise alcohol outlets (i.e. state stores), grocery stores/supermarkets and restaurants. We determined the total number of establishments and mean density values for all census tracts in Allegheny county for the years 2003 and 2009. These values were calculated for InfoUSA and D\&B data separately as well as for the combined InfoUSA and D\&B dataset. We then conducted a comparison of mean density values and correlations of the same measures between InfoUSA and D\&B.

\section{Results}

\section{Matching and manual review results}

For 2009, there were a total of 7,078 unique establishments represented in the combined dataset (results not shown). Out of the total 7,078 establishments, 3,071 were matches (i.e. a record of the establishments exists in both InfoUSA and D\&B databases); 1,255 were from InfoUSA only, and 2,752 were from D\&B only. Among establishments with XY coordinates, there were a total of 64 combinations of establishments that were reviewed manually, and 42 were deemed matches. Among those without XY coordinates, 131 were deemed matches out of 316 that were manually reviewed. For 2003, there were a total of 8,705 unique establishments represented in the combined dataset (results not shown). There were 3,071 records across both sources; 946 from InfoUSA only and 4,738 from D\&B only. Among establishments with XY coordinates, there were a total of 92 combinations of establishments that were reviewed manually, and 38 were deemed matches. Among those without XY coordinates, 204 were deemed matches out of 343 that were manually reviewed.

\section{Descriptive results}

We compared across datasets the total number of various types of establishments based on the primary and any SIC code (Tables 1a and 1b). Among establishments categorised by the primary SIC code, we found that combining the two data sources provided a greater number of establishment where establishments missing in one data source may have been included in the other data source. For example, in 2009, there were 540 alcohol outlets included in InfoUSA data, 703 in $\mathrm{D} \& \mathrm{~B}$, and combining the data sources produced 780 unique alcohol outlets. We also found that total number of establishments in D\&B tended to be higher than the number of establishments in InfoUSA. We saw this trend across the various types of establishments. We also found that combining the datasets produced a higher number of establishments than relying on only one source. When we examined all SIC codes (i.e. primary, secondary, etc.), we find that $\mathrm{D} \& \mathrm{~B}$ on average tended to have a higher number of establishments in each category compared to InfoUSA. In all categories, combining the two data sources resulted in a higher number of establishments compared to relying on one data source, similar to the patterns among the primary SIC code designation.

We also calculated the mean densities (per capita and area) for all census tracts in Allegheny county of establishments based on any SIC code, meaning establishments could be included in more than one category depending on the type of establishment (Tables $2 \mathrm{a}$ and $2 \mathrm{~b})$. Similar to the patterns seen in Tables $1 \mathrm{a}$ and $1 \mathrm{~b}$, the mean densities of the combined dataset were higher than for each single data source. For example, the mean density (population-based) of grocery stores per census tract in 2009 was 0.6 for InfoUSA, 12.6 for 
Table 1a. Total number of establishments per census tract for each data source in Allegheny county, PA, USA in 2003 and 2009 based on the primary SIC code.

\begin{tabular}{|c|c|c|c|c|c|c|}
\hline \multirow[t]{2}{*}{ Year } & \multicolumn{3}{|c|}{2003} & \multicolumn{3}{|c|}{2009} \\
\hline & InfoUSA & $\mathrm{D} \& \mathrm{~B}$ & Combined & InfoUSA & D\&B & Combined \\
\hline Alcohol outlets & 562 & 1,013 & 1,047 & 540 & 703 & 792 \\
\hline Grocery stores/supermarkets & 0 & 1,170 & 1,065 & 0 & 739 & 656 \\
\hline Restaurants & 2,152 & 3,350 & 3,951 & 2,439 & 2,583 & 3,337 \\
\hline Wholesale foods & 132 & 220 & 286 & 117 & 225 & 286 \\
\hline General/convenience stores & 64 & 398 & 417 & 147 & 337 & 384 \\
\hline Gas stations & 198 & 334 & 391 & 212 & 259 & 335 \\
\hline Pharmacies & 208 & 363 & 409 & 224 & 227 & 294 \\
\hline
\end{tabular}

Table 1b. Total number of establishments per census tract for each data source in Allegheny county, PA, USA in 2003 and 2009 based on any SIC code.

\begin{tabular}{|c|c|c|c|c|c|c|}
\hline \multirow[t]{2}{*}{ Year } & \multicolumn{3}{|c|}{2003} & \multicolumn{3}{|c|}{2009} \\
\hline & InfoUSA & $\mathrm{D} \& \mathrm{~B}$ & Combined & InfoUSA & $\mathrm{D} \& \mathrm{~B}$ & Combined \\
\hline Alcohol outlets & 669 & 1231 & 1,385 & 651 & 884 & 1,113 \\
\hline Grocery stores/supermarkets & 66 & 1245 & 1,304 & 75 & 842 & 900 \\
\hline Restaurants & 2,191 & 3,525 & 4,148 & 2,480 & 2,737 & 3,541 \\
\hline Wholesale foods & 135 & 253 & 319 & 125 & 253 & 328 \\
\hline General/convenience stores & 80 & 451 & 493 & 222 & 371 & 495 \\
\hline Gas stations & 198 & 360 & 417 & 212 & 272 & 347 \\
\hline Pharmacies & 208 & 383 & 429 & 225 & 250 & 317 \\
\hline
\end{tabular}

$\mathrm{D} \& \mathrm{~B}$, and 16.7 for the combined dataset. The median grocery store density (population-based) in 2009 was 0 (range 0-37.6) for InfoUSA, 4.3 (range 0-902.3) for D\&B and 4.5 (range 0-939.8) for the combined dataset (results not shown). The patterns of densities are similar for the per capita and area-based measures for 2009 and 2003. As can be seen in Tables $2 \mathrm{a}$ and $2 \mathrm{~b}$, the standard deviations for some of the density measures were quite high, indicating the range of establishments in areas that tended to be more commercial or were designated as shopping centres or malls.

We found a high correlation between InfoUSA and D\&B for the density measures for alcohol outlets, grocery stores, restaurants, wholesale foods and gas stations (Table 3). The correlations ranged from 0.32 to 0.85 among the population-based density measures and ranged from 0.32 to 0.83 among the area-based density measures. The highest correlations were for both restaurant density measures, and the lowest correlations were for both grocery store measures. We additionally evaluated the association between land zoned for commercial use and various densities for the individual data sources and combined database (results not shown). We did not find any major differences in the association between the density measures and land use for each of the data sources. ArcGIS was also used to develop density maps for Allegheny county. We included grocery store density maps for Allegheny county census tracts based on measures for InfoUSA only, $\mathrm{D} \& \mathrm{~B}$ only and then the combined dataset (Fig. 2). The darker regions indicate a higher density. In the map of InfoUSA, there are many census tracts with a density of 0 while there is more of a range throughout the region in the $\mathrm{D} \& \mathrm{~B}$ map. Although there were several tracts with a density of 0 , the map with the combined InfoUSA and D\&B data shows a wider range of densities throughout the region. We also saw a higher density in the combined data map, particularly within the centre of the map (within the city) compared to the maps of the separate datasets.

\section{Discussion}

The study presents a process and method of combing two secondary commercial data sources to capture the food and alcohol environment. Although this 
Table 2a. Establishment density per 10,000 people and census tract for each data source in Allegheny county, PA, USA in 2003 and 2009.

\begin{tabular}{|c|c|c|c|c|c|c|}
\hline \multirow[t]{2}{*}{ Year } & \multicolumn{3}{|c|}{2003} & \multicolumn{3}{|c|}{2009} \\
\hline & InfoUSA & $D \& B$ & Combined & InfoUSA & $\mathrm{D} \& \mathrm{~B}$ & Combined \\
\hline Alcohol outlets & $7.0(25.5)$ & $14.0(54.9)$ & $15.7(60.1)$ & $9.9(65)$ & $12.6(74.0)$ & $16.7(98.3)$ \\
\hline Grocery stores/supermarkets & $0.8(6.0)$ & $14.1(70.3)$ & $14.9(75.8)$ & $0.6(2.4)$ & $9.4(47.8)$ & $9.9(49.6)$ \\
\hline Restaurants & $25.4(91.6)$ & $38.3(125.5)$ & $46.1(156.3)$ & $33.2(160.1)$ & $32.9(137.5)$ & $44.3(198.5)$ \\
\hline Wholesale foods & $3.9(44.6)$ & $3.8(44.2)$ & $6.8(69.9)$ & $2.4(25.3)$ & $4.0(37.2)$ & $6.0(57.2)$ \\
\hline General/convenience stores & $0.7(2.5)$ & $3.5(4.7)$ & $4.0(5.4)$ & $2.6(13.5)$ & $2.9(4.4)$ & $4.8(14.5)$ \\
\hline Gas stations & $2.5(15.5)$ & $4.5(26.8)$ & $4.9(26.9)$ & $2.1(9.3)$ & $2.6(9.5)$ & $3.2(9.7)$ \\
\hline Pharmacies & $1.6(3.3)$ & $3.1(4.7)$ & $3.5(5.0)$ & $1.8(6.1)$ & $1.8(3.4)$ & $2.5(6.6)$ \\
\hline
\end{tabular}

Table 2b. Establishment density per square mile and census tract for each data source in Allegheny county, PA, USA in 2003 and 2009.

\begin{tabular}{|c|c|c|c|c|c|c|}
\hline \multirow[t]{2}{*}{ Year } & \multicolumn{3}{|c|}{2003} & \multicolumn{3}{|c|}{2009} \\
\hline & InfoUSA & $D \& B$ & Combined & InfoUSA & $\mathrm{D} \& \mathrm{~B}$ & Combined \\
\hline Alcohol outlets & $3.3(6.5)$ & $6.2(12.9)$ & $6.8(13.8)$ & $3.1(6.4)$ & $4.3(9.1)$ & $5.3(10.6)$ \\
\hline Grocery stores/supermarkets & $0.3(1.1)$ & $6.1(11.5)$ & $6.4(12.2)$ & $0.4(1.4)$ & $3.7(7.6)$ & $3.9(7.9)$ \\
\hline Restaurants & $10.2(23.7)$ & $16.0(32.3)$ & $18.9(38.8)$ & $11.4(26.2)$ & $12.3(26.1)$ & $15.9(33.5)$ \\
\hline Wholesale foods & $0.4(1.6)$ & $0.8(2.5)$ & $1.0(3.2)$ & $0.4(1.5)$ & $0.9(2.4)$ & $1.1(3.3)$ \\
\hline General/convenience stores & $0.3(1.0)$ & $2.0(3.7)$ & $2.2(3.8)$ & $0.9(2.1)$ & $1.5(2.6)$ & $2.0(3.6)$ \\
\hline Gas stations & $0.6(1.3)$ & $1.3(3.0)$ & $1.5(3.1)$ & $0.8(2.0)$ & $1.0(2.3)$ & $1.3(2.5)$ \\
\hline Pharmacies & $0.9(2.1)$ & $2.0(4.2)$ & $2.2(4.6)$ & $0.9(2.1)$ & $1.0(2.6)$ & $1.2(2.9)$ \\
\hline
\end{tabular}

Table 3. Spearman correlations between InfoUSA and D\&B for the various density measures 2009 .

\begin{tabular}{lcc}
\hline $\begin{array}{l}\text { Density of establishments } \\
\text { per 10,000 people }\end{array}$ & $\begin{array}{c}\text { Correlation } \\
\text { coefficient }\end{array}$ & P-value \\
\hline Alcohol outlets & 0.75 & $<0.001$ \\
Grocery stores/supermarkets & 0.32 & $<0.001$ \\
Restaurants & 0.85 & $<0.001$ \\
Wholesale foods & 0.44 & $<0.001$ \\
General/convenience stores & 0.49 & $<0.010$ \\
Gas stations & 0.58 & $<0.001$ \\
Pharmacies & 0.75 & $<0.010$ \\
\hline Density of establishments & Correlation & P-value \\
per mile & coefficient & \\
\hline Alcohol outlets & 0.79 & $<0.001$ \\
Grocery stores/supermarkets & 0.32 & $<0.001$ \\
Restaurants & 0.83 & $<0.001$ \\
Wholesale foods & 0.42 & $<0.001$ \\
General/convenience stores & 0.46 & $<0.001$ \\
Gas stations & 0.59 & $<0.001$ \\
Pharmacies & 0.76 & $<0.001$ \\
\hline
\end{tabular}

study is specific to InfoUSA and D\&B data mainly due to their increased usage in public health literature (Liese et al., 2010; Gustafson et al., 2012a), this process can be applied among other secondary and local data sources. We found that there were some differences in the total number and density of establishments between InfoUSA and D\&B. Combining the two data captured more establishments, but since we lacked comparable data from the same year (i.e. local historical data for 2003 and 2009), we could not determine whether we were under-counting or overcounting even when combining the data sources. Based on prior work, both sources typically undercount the true number of establishments (Liese et al., 2010). In our study, for some establishment categories, the range of combined establishments was approximately 40 to 900 compared to either single data source.

This study involves historical data (i.e. data from 2003), for which changes in the landscape of food, alcohol and other establishments could not be easily confirmed through other tools or methods such as online verification or "ground-truthing" (i.e. field sur- 
InfoUSA

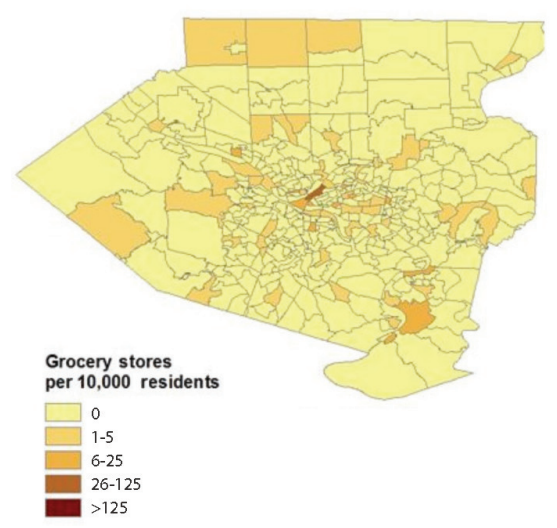

D\&B

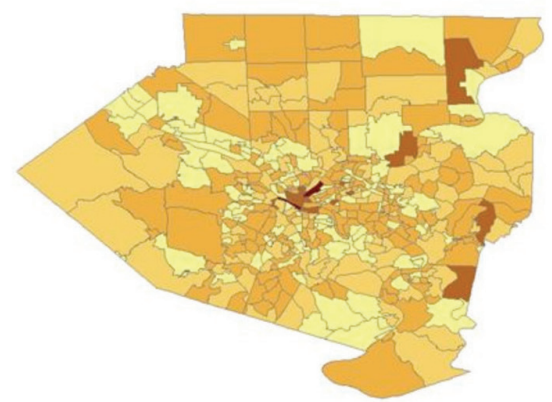

Combined

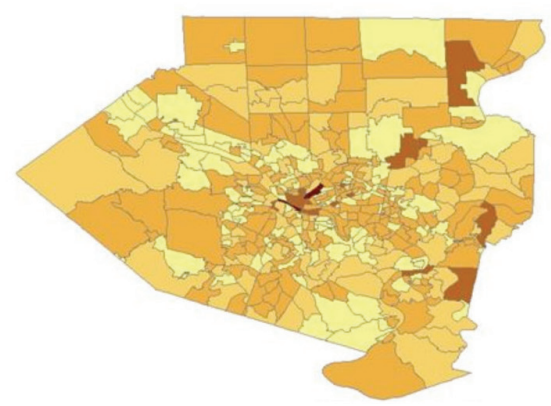

Fig. 2. Grocery store density maps (per capita) for the separate and combined commercial data sources for all census tracts in Allegheny county, PA, USA 2009. This figure includes grocery store density maps for each commercial data source, InfoUSA and $D \& B$, and then the final map for both data sources combined. Density was calculated for each census tract as the number of grocery stores per 10,000 residents. The darker regions indicate a higher density. Data are based on census tracts in Allegheny county, PR, USA in 2009.

vey to verify a location). Additionally, data from tax records, which could possibly be used for the purposes of obtaining information about locations of food and alcohol establishments, are subject to confidentiality restrictions, and the use of local food inspection data to capture food establishments differs from location to location in terms of format, address quality and electronic availability. Combining secondary commercial data sources and local data sources when available is a viable option for research examining patterns of establishments that cannot be verified through neighbourhood audits.

Both data sources included SIC taxonomy in classifying establishments. However, the methodology used by each company differs, influencing how establishments are categorised. The processes used by these companies in identifying businesses and collecting information from businesses are proprietary, which limits an understanding of the data quality and composition. As a result, we decided to include measures and analyses that included classifications from both data sources. One study that examined various ways of reclassifying establishments did not compare classification differences across data sources, but found that classifications stemming exclusively from commercial data sources may be more likely to categorise establishments as "less healthy" options (e.g. as convenience stores or limited- service restaurants versus supermarkets or grocery stores) (Ohri-Vachaspati et al., 2011). Additionally, further work is needed to ensure consistent acquisition of information, includ- ing how establishments are defined across time and geographic region for purposes other than marketing (Ohri-Vachaspati et al., 2011). In our study, we found some differences across the data sources in categorising restaurants and bars where InfoUSA primarily classified certain establishments as restaurants while D\&B classified the same type establishment as a bar. In other cases, both classifications were provided for the establishment; one under the primary SIC and the other assigned to the secondary SIC. We identified similar patterns of differences in classification as well as missing data for various grocery stores and supermarkets. In addition to differences in classification, we found through name recognition and review that some establishments were not included in either data source. Our study team was able to fill in important gaps in information by using more than one data source, particularly when using historical data. Since our study relied upon secondary data and many other studies may use secondary data sources to understand such environments, we could not control for these inaccuracies.

In our study, we used a local geocoding reference file provided by the Allegheny county GIS department to geocode establishments. We were able to use local street and rooftop point data developed by our local county/city planning. Due to potential changes in streets and new developments in our area, local street network data provides the most up-to-date information for accurate mapping. Local street and rooftop point data may be of better quality (Roongpiboonsopit 
and Karimi, 2010), especially given rigorous processes are in place to validate and update information. Geocoding software companies may not have more recent changes in an area and would, therefore, be unable to geocode accurately. Researchers should attempt to geocode addresses based on local street files when available rather than relying solely on the files provided by national software packages.

Finally, we examined potential visual differences in densities using maps of census tracts across the county. We were able to see some patterns across regions based on location within the county. Further work could examine whether these differences or patterns are systematic or based on other geographic characteristics. Future studies attempting to validate their secondary data through "ground-truthing" of a subset of communities in their area, considering other characteristics of the neighbourhood, such as the sociodemographics of the neighbourhood, may also provide additional insight into systematic differences across data sources.

\section{Conclusion}

The approach and rationale for combining commercial data to construct a database of the neighbourhood food and alcohol environment can be applied in other communities and geographic regions particularly for studies interested in understanding trends over time. For studies that cannot audit communities or conduct primary data collection of the resources in all regions of interests, these methods will be useful. By applying multiple data sources, we produced more establishments and coverage than relying only on one data source, potentially having an influence on how neighbourhoods are ultimately characterised. Finally, future studies should consider how differences across data sources may be associated with other neighbourhood characteristics and the relationship with important health outcomes.

\section{Acknowledgements}

This study was made possible in part by support from The Aetna Foundation (11-02359), Kellogg Health Scholars Program (WK Kellogg Foundation), NIAAA (T32 AA0745326), and The Center for Disease Control (U01-CE001630). The views presented here are those of the author and not necessarily those of the funding agencies, its directors, officers or staff. We also thank Dr. Kevin H. Kim for his statistical insight.

\section{References}

Ahern J, Margerison-Zilko C, Hubbard A, Galea S, 2013. Alcohol outlets and binge drinking in urban neighborhoods: the implications of nonlinearity for intervention and policy. Am J Public Health 103, e81-e87.

Feng J, Glass TA, Curriero FC, Stewart WF, Schwartz BS, 2010. The built environment and obesity: a systematic review of the epidemiologic evidence. Health Place 16, 175-190.

Gustafson A, Hankins S, Jilcott S, 2012a. Measures of the consumer food store environment: a systematic review of the evidence 2000-2011. J Community Health, 37 897-911.

Gustafson A, Sharkey J, Samuel-Hodge CD, Jones-Smith JC, Cai J, Ammerman AS, 2012b. Food store environment modifies intervention effect on fruit and vegetable intake among low-income women in North Carolina. J Nutr Metab 2012, 932653.

Han E, Powell LM, Zenk SN, Rimkus L, Ohri-Vachaspati P, Chaloupka FJ, 2012. Classification bias in commercial business lists for retail food stores in the U.S. Int J Behav Nutr Phys Act 9, 46.

Janevic T, Borrell LN, Savitz DA, Herring AH, Rundle A, 2010. Neighbourhood food environment and gestational diabetes in New York City. Paediatr Perinat Epidemiol 24, 249-254.

Karimi HA, Durcik M, Rasdorf W, 2004. Evaluation of uncertainties associated with geocoding techniques. Comput-Aided Civ Inf 19, 170-185.

Liese AD, Colabianchi N, Lamichhane AP, Barnes TL, Hibbert JD, Porter DE, Nichols MD, Lawson AB, 2010. Validation of 3 food outlet databases: completeness and geospatial accuracy in rural and urban food environments. Am J Epidemiol 172, 1324-1333.

Ohri-Vachaspati P, Martinez D, Yedidia MJ, Petlick N, 2011. Improving data accuracy of commercial food outlet databases. Am J Health Promot 26, 116-122.

Roongpiboonsopit D, Karimi HA, 2010. Quality assessment of online street and rooftop geocoding services. Cartogr Geogr Inf Sci 37, 301-318.

Shier V, An R, Sturm R, 2012. Is there a robust relationship between neighbourhood food environment and childhood obesity in the USA? Public Health 126, 723-730.

Shimotsu ST, Jones-Webb RJ, Maclehose RF, Nelson TF, Forster JL, Lytle LA, 2013. Neighborhood socioeconomic characteristics, the retail environment, and alcohol consumption: a multilevel analysis. Drug Alcohol Depend 132, 449-456. 


\section{Supplement}

Table A. SIC classifications and categorisations used for establishments.

\begin{tabular}{|c|c|c|c|}
\hline Category & SIC & SIC EXT & SIC Title \\
\hline \multirow[t]{21}{*}{ On-premise alcohol outlet } & 5813 & & Drinking places - Alcoholic beverages \\
\hline & & 581301 & Bars \\
\hline & & 581302 & Discotheques \\
\hline & & 581303 & Cocktail lounges \\
\hline & & 581304 & Night clubs \\
\hline & & 581305 & Pubs \\
\hline & & 581306 & Cabarets \\
\hline & & 581307 & Comedy clubs \\
\hline & & 581308 & Night clubs information service \\
\hline & & 581309 & Karaoke clubs \\
\hline & & 58130000 & Drinking places \\
\hline & & 58130100 & Bars and lounges \\
\hline & & 58130101 & Bar (drinking places) \\
\hline & & 58130102 & Beer garden (drinking places) \\
\hline & & 58130103 & Cocktail lounge \\
\hline & & 58130104 & Saloon \\
\hline & & 58130105 & Tavern (drinking places) \\
\hline & & 58130106 & Wine bar \\
\hline & & 58130200 & Night clubs \\
\hline & & 58130201 & Cabaret \\
\hline & & 58130202 & Discotheque \\
\hline \multirow[t]{24}{*}{ Off-premise alcohol outlet } & 5181 & & Wholesale beer and ale \\
\hline & & 518101 & Beer \& ale-wholesale \\
\hline & & 51810000 & Beer and ale \\
\hline & & 51819900 & Beer and ale, (NEC) \\
\hline & & 51819901 & Ale \\
\hline & & 51819902 & Beer and other fermented malt liquors \\
\hline & & 51819903 & Porter \\
\hline & 5182 & & Wholesale wines and distilled alcoholic beverages \\
\hline & & 518201 & Liquors-wholesale \\
\hline & & 518202 & Distillers representatives \\
\hline & & 518203 & Wines-wholesale \\
\hline & & 518204 & Wine brokers \\
\hline & & 518205 & Distillery equipment \& supplies (WHLS) \\
\hline & & 518206 & Brewers equipment $\&$ supplies (WHLS) \\
\hline & & 518207 & Wines-sacramental (WHLS) \\
\hline & & 51820000 & Wine and distilled beverages \\
\hline & & 51820100 & Wine \\
\hline & & 51820101 & Brandy and brandy spirits \\
\hline & & 51820102 & Wine coolers, alcoholic \\
\hline & & 51820200 & Liquor \\
\hline & & 51820201 & Cocktails, alcoholic: premixed \\
\hline & & 51820202 & Neutral spirits \\
\hline & & 51829900 & Wine and distilled beverages, (NEC) \\
\hline & & 51829901 & Bottling wines and liquors \\
\hline
\end{tabular}

WHLS = wholesale; NEC $=$ not elsewhere classified. 


\begin{tabular}{|c|c|c|c|}
\hline Category & SIC & SIC EXT & SIC Title \\
\hline \multirow[t]{14}{*}{ Off-premise alcohol outlet } & 5921 & & Liquor stores \\
\hline & & 592101 & Cocktail mixes \\
\hline & & 592102 & Liquors-retail \\
\hline & & 592103 & Wines-retail \\
\hline & & 592104 & Beer $\&$ ale-retail \\
\hline & & 592105 & Cordials \\
\hline & & 592106 & Daiquiri shops \\
\hline & & 592107 & Tasting rooms \\
\hline & & 59210000 & Liquor stores \\
\hline & & 59210100 & Wine and beer \\
\hline & & 59210101 & Beer (packaged) \\
\hline & & 59210102 & Wine \\
\hline & & 59219900 & Liquor stores, (NEC) \\
\hline & & 59219901 & Hard liquor \\
\hline \multirow[t]{35}{*}{ Wholesale foods, suppliers and distributors } & 5141 & & Wholesale groceries - general line \\
\hline & & 514101 & Food products (WHLS) \\
\hline & & 514102 & Food brokers \\
\hline & & 514103 & Foods-dehydrated (WHLS) \\
\hline & & 514104 & Mexican food products-wholesale \\
\hline & & 514105 & Grocers-wholesale \\
\hline & & 514106 & Delicatessens-wholesale \\
\hline & & 514107 & Bulk foods-wholesale \\
\hline & & 514108 & Delicatessen products-wholesale \\
\hline & & 514109 & Markets \& grocers equip \& supls (WHLS) \\
\hline & & 514110 & Brokers-grocery \\
\hline & & 514111 & Food agents \\
\hline & & 514112 & Food service-supplies (WHLS) \\
\hline & & 514113 & Kosher food products-wholesale \\
\hline & & 514114 & Macaroni products (WHLS) \\
\hline & & 514115 & Horseradish (WHLS) \\
\hline & & 514116 & Japanese food products-whls \& mfrs \\
\hline & & 51410000 & Groceries, general line \\
\hline & & 51419900 & Groceries, general line, (NEC) \\
\hline & & 51419901 & Food brokers \\
\hline & 5142 & & Wholesale packaged frozen foods \\
\hline & & 514201 & Frozen foods-wholesale \\
\hline & & 514202 & Fruit juices (WHLS) \\
\hline & & 514203 & Meats-frozen (WHLS) \\
\hline & & 51420100 & Frozen vegetables and fruit products \\
\hline & & 51420101 & Fruit juices, frozen \\
\hline & & 51420102 & Fruit pies, frozen \\
\hline & & 51420103 & Fruits, frozen \\
\hline & & 51420104 & Vegetables, frozen \\
\hline & & 51420200 & Frozen fish, meat and poultry \\
\hline & & 51420201 & Fish, frozen: packaged \\
\hline & & 51420202 & Meat pies, frozen \\
\hline & & 51420203 & Meat, frozen: packaged \\
\hline & & 51420204 & Poultry pies, frozen \\
\hline & & 51420205 & Poultry, frozen: packaged \\
\hline
\end{tabular}




\begin{tabular}{|c|c|c|c|}
\hline Category & SIC & SIC EXT & SIC Title \\
\hline & & 51429900 & Packaged frozen goods, (NEC) \\
\hline & & 51429901 & Bakery products, frozen \\
\hline & & 51429902 & Dinners, frozen \\
\hline & & 51429903 & Soup, frozen \\
\hline & 5143 & & Wholesale dairy products except dried or canned \\
\hline & & 514301 & Cheese-wholesale \\
\hline & & 514302 & Butter (WHLS) \\
\hline & & 514303 & Dairy products-wholesale \\
\hline & & 514304 & Ice cream \& frozen desserts-distributors \\
\hline & & 514305 & Ice cream mixes (WHLS) \\
\hline & & 514306 & Yogurt-wholesale \\
\hline & & 514307 & Milk buyers \\
\hline & & 514308 & Cheese-importing (WHLS) \\
\hline & & 51430100 & Milk \\
\hline & & 51430101 & Milk and cream, fluid \\
\hline & & 51430102 & Milk cooling stations \\
\hline & & 51430103 & Milk depot \\
\hline & & 51439900 & Dairy products, except dried or canned (NEC) \\
\hline & & 51439901 & Butter \\
\hline & & 51439902 & Cheese \\
\hline & & 51439903 & Dairy depot \\
\hline & & 51439904 & Frozen dairy desserts \\
\hline & & 51439905 & Ice cream and ices \\
\hline & & 51439906 & Yogurt \\
\hline & 5144 & & Wholesale poultry and poultry products \\
\hline & & 514401 & Poultry brokers \\
\hline & & 514402 & Poultry services (WHLS) \\
\hline & & 514403 & Eggs (WHLS) \\
\hline & & 514404 & Poultry-wholesale \\
\hline & & 51440000 & Poultry and poultry products \\
\hline & & 51449900 & Poultry and poultry products, (NEC) \\
\hline & & 51449901 & Eggs \\
\hline & & 51449902 & Eggs:cleaning, oil treating, packing, and grading \\
\hline & & 51449903 & Poultry products, (NEC) \\
\hline & & 51449904 & Poultry: live, dressed or frozen (unpackaged) \\
\hline & 5145 & & Wholesale confectionary \\
\hline & & 514501 & Candy \& confectionery-wholesale \\
\hline & & 514502 & Candy \& confectionery-brokers \\
\hline & & 514503 & Concessionaires equip \& supplies (WHLS) \\
\hline & & 514504 & Potato chips (WHLS) \\
\hline & & 514505 & Popcorn \& popcorn supplies-wholesale \\
\hline & & 514506 & Syrups-wholesale \\
\hline & & 514507 & Pretzels (WHLS) \\
\hline & & 514508 & Candy \& confectionery-mfrs supls (WHLS) \\
\hline & & 514509 & Ice cream cone-distributors \\
\hline & & 514510 & Nuts-edible-wholesale $\&$ processing \\
\hline & & 514511 & Corn chips (WHLS) \\
\hline & & 514512 & Pistachios \\
\hline & & 51450000 & Confectionery \\
\hline
\end{tabular}




\begin{tabular}{|c|c|c|c|}
\hline Category & SIC & SIC EXT & SIC Title \\
\hline & & 51450100 & Fountain supplies \\
\hline & & 51450101 & Fruits, fountain \\
\hline & & 51450102 & Syrups, fountain \\
\hline & & 51450103 & Toppings, soda fountain \\
\hline & & 51450200 & Snack foods \\
\hline & & 51450201 & Corn chips \\
\hline & & 51450202 & Nuts, salted or roasted \\
\hline & & 51450203 & Popcorn and supplies \\
\hline & & 51450204 & Potato chips \\
\hline & & 51450205 & Pretzels \\
\hline & & 51459900 & Confectionery, (NEC) \\
\hline & & 51459901 & Candy \\
\hline & & 51459902 & Chewing gum \\
\hline & 5146 & & Wholesale fish and seafoods \\
\hline & & 514601 & Seafood-wholesale \\
\hline & & 514602 & Oysters-wholesale \\
\hline & & 514603 & Shrimp-wholesale \\
\hline & & 514604 & Fish \& seafood-brokers \\
\hline & & 514605 & Fish buyers-fresh water \\
\hline & & 51460000 & Fish and seafoods \\
\hline & & 51469900 & Fish and seafoods, (NEC) \\
\hline & & 51469901 & Fish, cured \\
\hline & & 51469902 & Fish, fresh \\
\hline & & 51469903 & Fish, frozen, unpackaged \\
\hline & & 51469904 & Seafoods \\
\hline & 5147 & & Wholesale meats and meat products \\
\hline & & 514701 & Butchering \\
\hline & & 514702 & Meat jobbers \\
\hline & & 514703 & Meat brokers \\
\hline & & 514704 & Meat-wholesale \\
\hline & & 514705 & Sausages-wholesale \\
\hline & & 514706 & Pork dealers-wholesale \\
\hline & & 514707 & Frankfurters \& rolls (WHLS) \\
\hline & & 514708 & Bacon $\&$ ham curers $\&$ suppliers \\
\hline & & 514711 & Meat-kosher-wholesale \\
\hline & & 51470000 & Meats and meat products \\
\hline & & 51479900 & Meats and meat products, (NEC) \\
\hline & & 51479901 & Lard \\
\hline & & 51479902 & Meat brokers \\
\hline & & 51479903 & Meats, cured or smoked \\
\hline & & 51479904 & Meats, fresh \\
\hline & 5148 & & Wholesale fresh fruits and vegetables \\
\hline & & 514801 & Fruits $\&$ vegetables-wholesale \\
\hline & & 514802 & Potatoes-wholesale \\
\hline & & 514803 & Produce-brokers \\
\hline & & 514804 & Fruits \& vegetables-brokers \\
\hline & & 514805 & Fruits \& vegetables-growers $\&$ shippers \\
\hline & & 514806 & Citrus buyers \\
\hline & & 514807 & Citrus fruits (WHLS) \\
\hline
\end{tabular}




\begin{tabular}{|c|c|c|c|}
\hline Category & SIC & SIC EXT & SIC Title \\
\hline & & 514808 & Bananas-wholesale \\
\hline & & 514809 & Citrus fruit products-wholesale \\
\hline & & 514810 & Fruit baskets-gift-wholesale \\
\hline & & 514811 & Apple brokers \\
\hline & & 514812 & Tomatoes-wholesale \\
\hline & & 514813 & Apple shippers \\
\hline & & 514814 & Cherries-maraschino (WHLS) \\
\hline & & 514815 & GARDENS-U-PICK (WHLS) \\
\hline & & 51480000 & Fresh fruits and vegetables \\
\hline & & 51480100 & Fruits \\
\hline & & 51480101 & Banana ripening \\
\hline & & 51480102 & Fruits, fresh \\
\hline & & 51480200 & Vegetables \\
\hline & & 51480201 & Potatoes, fresh \\
\hline & & 51480202 & Vegetables, fresh \\
\hline & 5149 & & $\begin{array}{l}\text { Wholesale groceries and related products not } \\
\text { elsewhere classified }\end{array}$ \\
\hline & & 514901 & Molasses (WHLS) \\
\hline & & 514902 & Bakers-wholesale \\
\hline & & 514903 & Baby foods (WHLS) \\
\hline & & 514904 & Chili \& chili products (WHLS) \\
\hline & & 514905 & Coffee $\&$ tea-wholesale \\
\hline & & 514906 & Chocolate \& cocoa (WHLS) \\
\hline & & 514907 & Commission merchants \\
\hline & & 514908 & Coffee roasting (WHLS) \\
\hline & & 514909 & Condiments \& sauces (WHLS) \\
\hline & & 514910 & Pet foods-wholesale \\
\hline & & 514911 & Foods-foreign (WHLS) \\
\hline & & 514912 & Fruits-dried (WHLS) \\
\hline & & 514913 & Flour (WHLS) \\
\hline & & 514914 & Health food products-wholesale \\
\hline & & 514915 & Malts \& hops (WHLS) \\
\hline & & 514916 & Honey (WHLS) \\
\hline & & 514917 & Yeast (WHLS) \\
\hline & & 514918 & Oils-vegetable (WHLS) \\
\hline & & 514919 & Olives (WHLS) \\
\hline & & 514920 & Pizza-wholesale \\
\hline & & 514921 & Rice-wholesale \\
\hline & & 514922 & Pizza equipment $\&$ supplies (WHLS) \\
\hline & & 514923 & Salads (WHLS) \\
\hline & & 514924 & Soft drinks (WHLS) \\
\hline & & 514925 & Sandwiches-wholesale \\
\hline & & 514926 & Tea-wholesale \\
\hline & & 514927 & Sugar-brokers \& wholesalers \\
\hline & & 514928 & Tortillas (WHLS) \\
\hline & & 514929 & Clams (WHLS) \\
\hline & & 514930 & Pasta (WHLS) \\
\hline & & 514931 & Soybean products (WHLS) \\
\hline & & 514932 & Flavoring extracts (WHLS) \\
\hline
\end{tabular}




\begin{tabular}{|c|c|c|c|}
\hline Category & SIC & SIC EXT & SIC Title \\
\hline & & 514933 & Mayonnaise \& salad dressings (WHLS) \\
\hline & & 514934 & Tamales (WHLS) \\
\hline & & 514935 & Ravioli (WHLS) \\
\hline & & 514936 & Corn products (WHLS) \\
\hline & & 514937 & Beverages (WHLS) \\
\hline & & 514938 & Spices-wholesale \\
\hline & & 514939 & Food service-distributors \\
\hline & & 514940 & Bagels-wholesale \\
\hline & & 514941 & Barbecue-wholesale (sauce) \\
\hline & & 514942 & Bird feed-wholesale \\
\hline & & 514943 & Canned goods-wholesale \\
\hline & & 514944 & Chinese foods-wholesale \\
\hline & & 514945 & Coffee break service $\&$ supplies-wholesale \\
\hline & & 514946 & Doughnuts-wholesale \\
\hline & & 514947 & Food specialties-wholesale \\
\hline & & 514948 & Maple sugar \& syrup-wholesale \\
\hline & & 514949 & Natural foods-wholesale \\
\hline & & 514950 & Pickles \& pickle products-wholesale \\
\hline & & 514951 & Pies-wholesale \\
\hline & & 514952 & Jams \& preserves \\
\hline & & 514953 & Provisions-wholesale \\
\hline & & 514954 & Salt-wholesale \\
\hline & & 514955 & Wild rice-wholesale \\
\hline & & 514956 & Flavoring extracts-raw materialswholesale \\
\hline & & 514957 & Food facilities (WHLS) \\
\hline & & 514958 & Cocoa (WHLS) \\
\hline & & 514959 & Cookies \& crackers-wholesale \\
\hline & & 514960 & Tea bag packers (WHLS) \\
\hline & & 514961 & Distributor-groceries \\
\hline & & 514962 & Cider-wholesale \\
\hline & & 514963 & Milk-powdered (WHLS) \\
\hline & & 514964 & Italian food products-wholesale \\
\hline & & 514965 & Malted milk (WHLS) \\
\hline & & 514966 & Homeopathic suppliers (WHLS) \\
\hline & & 514967 & Box lunches-wholesale \\
\hline & & 514968 & Oils-edible (WHLS) \\
\hline & & 514969 & Olive oil wholesale \\
\hline & & 514970 & Baby foods retail \\
\hline & & 51490000 & Groceries and related products, (NEC) \\
\hline & & 51490100 & Cooking oils and shortenings \\
\hline & & 51490101 & Cooking oils \\
\hline & & 51490102 & Margarine \\
\hline & & 51490103 & Oleomargarine \\
\hline & & 51490104 & Shortening, vegetable \\
\hline & & 51490200 & Pet foods \\
\hline & & 51490201 & Cat food \\
\hline & & 51490202 & Dog food \\
\hline & & 51490300 & Seasonings, sauces, and extracts \\
\hline & & 51490301 & Condiments \\
\hline
\end{tabular}




\begin{tabular}{|c|c|c|c|}
\hline Category & SIC & SIC EXT & SIC Title \\
\hline & & 51490302 & Flavourings and fragrances \\
\hline & & 51490303 & Fruit peel \\
\hline & & 51490304 & Hop extract \\
\hline & & 51490305 & Malt \\
\hline & & 51490306 & Malt extract \\
\hline & & 51490307 & Salad dressing \\
\hline & & 51490308 & Salt, edible \\
\hline & & 51490309 & Sauces \\
\hline & & 51490310 & Spices and seasonings \\
\hline & & 51490400 & Pasta and rice \\
\hline & & 51490401 & Macaroni \\
\hline & & 51490402 & Rice, polished \\
\hline & & 51490403 & Spaghetti \\
\hline & & 51490500 & Beverages, except coffee and tea \\
\hline & & 51490501 & Beverage concentrates \\
\hline & & 51490502 & Juices \\
\hline & & 51490503 & Mineral or spring water bottling \\
\hline & & 51490504 & Soft drinks \\
\hline & & 51490505 & Water, distilled \\
\hline & & 51490600 & Organic and diet food \\
\hline & & 51490601 & Diet foods \\
\hline & & 51490602 & Health foods \\
\hline & & 51490603 & Natural and organic foods \\
\hline & & 51490604 & Specialty food items \\
\hline & & 51490700 & Crackers, cookies, and bakery products \\
\hline & & 51490701 & Bakery products \\
\hline & & 51490702 & Cookies \\
\hline & & 51490703 & Crackers \\
\hline & & 51490800 & Dried or canned foods \\
\hline & & 51490801 & Canned goods: fruit, vegetables, seafood, meats, etc. \\
\hline & & 51490802 & Dairy products, dried or canned \\
\hline & & 51490803 & Fruits, dried \\
\hline & & 51490804 & Milk, canned or dried \\
\hline & & 51490805 & Soups, except frozen \\
\hline & & 51490900 & Coffee and tea \\
\hline & & 51490901 & Coffee, green or roasted \\
\hline & & 51490902 & Tea \\
\hline & & 51490903 & Tea bagging \\
\hline & & 51491000 & Sugar, honey, molasses, and syrups \\
\hline & & 51491001 & Honey \\
\hline & & 51491002 & Molasses, industrial \\
\hline & & 51491003 & Sugar, refined \\
\hline & & 51491004 & Syrups, except for fountain use \\
\hline & & 51491100 & Baking supplies \\
\hline & & 51491101 & Flour \\
\hline & & 51491102 & Starch \\
\hline & & 51491103 & Wet corn milling products \\
\hline & & 51491104 & Yeast \\
\hline & & 51499900 & Groceries and related products, (NEC) \\
\hline
\end{tabular}




\begin{tabular}{|c|c|c|c|}
\hline Category & SIC & SIC EXT & SIC Title \\
\hline & & 51499901 & Breakfast cereals \\
\hline & & 51499902 & Chocolate \\
\hline & & 51499903 & Cocoa \\
\hline & & 51499904 & Food gift baskets \\
\hline & & 51499905 & Pickles, preserves, jellies, and jams \\
\hline & & 51499906 & Pizza supplies \\
\hline & & 51499907 & Sandwiches \\
\hline & & 51499908 & Sausage casings \\
\hline & & 51499909 & Wine makers' equipment and supplies \\
\hline & & 51499910 & Sandwich supplies \\
\hline & & 51499911 & Breading mixes \\
\hline \multirow[t]{28}{*}{ General Convience Stores } & 5331 & & Variety stores \\
\hline & & 533101 & Variety stores \\
\hline & & 533102 & Trading posts \\
\hline & & 533103 & Soap mitts \\
\hline & & 533104 & Clothes posts \\
\hline & & 533105 & Hula supplies-retail \\
\hline & & 53310000 & Variety stores \\
\hline & 5399 & & Miscellaneous general merchandise store \\
\hline & & 539901 & General merchandise-retail \\
\hline & & 539902 & Country stores \\
\hline & & 539903 & Bead strings \\
\hline & & 539904 & Tote boxes pans $\&$ trays \\
\hline & & 539905 & Farmers co-op retail stores \\
\hline & & 539906 & Car seats-children \\
\hline & & 539907 & Sponges-retail \\
\hline & & 53990000 & Miscellaneous general merchandise stores \\
\hline & & 53999900 & Miscellaneous general merchandise stores, (NEC) \\
\hline & & 53999901 & Army-Navy goods stores \\
\hline & & 53999902 & Catalog showroom stores \\
\hline & & 53999903 & Country general stores \\
\hline & & 53999904 & Duty-free stores \\
\hline & & 53999905 & Surplus and salvage stores \\
\hline & & 53999906 & Warehouse club stores \\
\hline & 5411 & & Grocery stores \\
\hline & & 541103 & Convenience stores \\
\hline & & 54110200 & Convenience stores \\
\hline & & 54110201 & Convenience stores, chain \\
\hline & & 54110202 & Convenience stores, independent \\
\hline \multirow[t]{10}{*}{ Gas Stations } & 5541 & & Gasoline service stations \\
\hline & & 554101 & Service stations-gasoline $\&$ oil \\
\hline & & 554102 & Gas-diesel \\
\hline & & 554103 & Truck stops \& plazas \\
\hline & & 554104 & Gas-leaded/lead-free \\
\hline & & 554105 & Kerosene \\
\hline & & 554106 & Service stations-marine \\
\hline & & 554107 & Oils-lubricating-retail \\
\hline & & 554110 & Alternative fuels \\
\hline & & 554111 & Diesel exhaust fluid \\
\hline
\end{tabular}




\begin{tabular}{|c|c|c|c|}
\hline Category & SIC & SIC EXT & SIC Title \\
\hline & & 554112 & Electric charging station \\
\hline & & 55410000 & Gasoline service stations \\
\hline & & 55419900 & Gasoline service stations, (NEC) \\
\hline & & 55419901 & Filling stations, gasoline \\
\hline & & 55419902 & Marine service station \\
\hline & & 55419903 & Truck stops \\
\hline \multirow{42}{*}{$\begin{array}{l}\text { Grocery Stores/Supermarkets \& } \\
\text { other food markets }\end{array}$} & 5411 & & Grocery stores \\
\hline & & & \\
\hline & & 541101 & Food markets \\
\hline & & 541102 & Snack products \\
\hline & & 541104 & Food products-retail \\
\hline & & 541105 & Grocers-retail \\
\hline & & 541106 & Markets-kosher \\
\hline & & 541107 & Grocers-ethnic foods \\
\hline & & 541108 & Grocers-health foods \\
\hline & & 541109 & Grocers-take-out foods \\
\hline & & 54110000 & Grocery stores \\
\hline & & 54110100 & Supermarkets \\
\hline & & 54110101 & Supermarkets, chain \\
\hline & & 54110102 & $\begin{array}{l}\text { Supermarkets, greater than } 100,000 \text { square feet } \\
\text { (hypermarket) }\end{array}$ \\
\hline & & 54110103 & Supermarkets, independent \\
\hline & & 54110104 & Supermarkets, $55,000-65,000$ square feet (superstore) \\
\hline & & 54110105 & Supermarkets, $66,000-99,000$ square feet \\
\hline & & 54119900 & Grocery stores, (NEC) \\
\hline & & 54119901 & Cooperative food stores \\
\hline & & 54119902 & Delicatessen stores \\
\hline & & 54119903 & Frozen food and freezer plans, except meat \\
\hline & & 54119904 & Grocery stores, chain \\
\hline & & 54119905 & Grocery stores, independent \\
\hline & 5421 & & Meat and seafood markets including \\
\hline & & & freezer provisioners \\
\hline & & 542101 & Seafood-retail \\
\hline & & 542102 & Food plans \\
\hline & & 542103 & Frozen foods-retail \\
\hline & & 542104 & Meat cutting service \\
\hline & & 542105 & Lobsters \\
\hline & & 542106 & Ham specialty stores \\
\hline & & 542107 & Meat-retail \\
\hline & & 542108 & Sausages \\
\hline & & 542109 & Shrimp-retail \\
\hline & & 542110 & Caviar \\
\hline & & 542111 & Meat markets-kosher \\
\hline & & 542113 & Hams \\
\hline & & 542114 & Smoked foods \\
\hline & & 542115 & Meat for freezers \\
\hline & & 542116 & Crab meat \\
\hline & & 542117 & Meats-barbecued \\
\hline & & 542118 & Smoking \& curing service \\
\hline
\end{tabular}




\begin{tabular}{|c|c|c|c|}
\hline Category & SIC & SIC EXT & SIC Title \\
\hline & & 542119 & Freezers-provisioning \\
\hline & & 54210000 & Meat and fish markets \\
\hline & & 54210100 & Fish and seafood markets \\
\hline & & 54210101 & Fish markets \\
\hline & & 54210102 & Seafood markets \\
\hline & & 54210200 & Meat markets, including freezer provisioners \\
\hline & & 54210201 & Food and freezer plans, meat \\
\hline & & 54210202 & Freezer provisioners, meat \\
\hline & 5431 & & Fruit and vegetable markets \\
\hline & & 543101 & Fruits $\&$ vegetables $\&$ produce-retail \\
\hline & & 543102 & farm markets \\
\hline & & 543103 & Fruit packages \\
\hline & & 543104 & Juices-retail \\
\hline & & 543105 & Fruits-glace \\
\hline & & 543106 & Pick-your-own fruit $\&$ vegetables \\
\hline & & 54310000 & Fruit and vegetable markets \\
\hline & & 54319900 & Fruit and vegetable markets, (NEC) \\
\hline & & 54319901 & Fruit stands or markets \\
\hline & & 54319902 & Vegetable stands or markets \\
\hline & 5441 & & Candy, nut and confectionery stores \\
\hline & & 544101 & Candy \& confectionery-retail \\
\hline & & 544102 & Nuts-edible \\
\hline & & 544103 & Popcorn $\&$ popcorn supplies \\
\hline & & 544104 & Candy making supplies \\
\hline & & 544105 & Wedding candy \& confectioneries \\
\hline & & 544106 & Candy \& cookie arrangements \\
\hline & & 54410000 & Candy, nut, and confectionery stores \\
\hline & & 54419900 & Candy, nut, and confectionery stores, (NEC) \\
\hline & & 54419901 & Candy \\
\hline & & 54419902 & Confectionery \\
\hline & & 54419903 & Confectionery produced for direct sale on the premises \\
\hline & & 54419904 & Nuts \\
\hline & & 54419905 & Popcorn, including caramel corn \\
\hline & 5451 & & Dairy products stores \\
\hline & & 545101 & Dairy products-retail \\
\hline & & 545102 & Yogurt \\
\hline & & 545103 & Cheese \\
\hline & & 54510000 & Dairy products stores \\
\hline & & 54519900 & Dairy products stores, (NEC) \\
\hline & & 54519901 & Butter \\
\hline & & 54519902 & Cheese \\
\hline & & 54519903 & Ice cream (packaged) \\
\hline & & 54519904 & Milk \\
\hline & 5461 & & Retail bakeries \\
\hline & & 546101 & Bagels \\
\hline & & 546102 & Bakers-retail \\
\hline & & 546103 & Bakers-cake \& pie \\
\hline & & 546104 & Pies \\
\hline & & 546105 & Doughnuts \\
\hline
\end{tabular}




\begin{tabular}{|c|c|c|c|}
\hline Category & SIC & SIC EXT & SIC Title \\
\hline & & 546106 & Cake decorating \\
\hline & & 546107 & Cookies \& crackers \\
\hline & & 546108 & Pretzels-retail \\
\hline & & 546109 & Cookie shops \\
\hline & & 546110 & Muffins \\
\hline & & 546111 & Matzos \\
\hline & & 546112 & Cake decorating instruction $\&$ supplies \\
\hline & & 54610000 & Retail bakeries \\
\hline & & 54619900 & Retail bakeries, (NEC) \\
\hline & & 54619901 & Bagels \\
\hline & & 54619902 & Bread \\
\hline & & 54619903 & Cakes \\
\hline & & 54619904 & Cookies \\
\hline & & 54619905 & Doughnuts \\
\hline & & 54619906 & Pastries \\
\hline & & 54619907 & Pies \\
\hline & & 54619908 & Pretzels \\
\hline & 5499 & & Miscellaneous food stores \\
\hline & & 549901 & Health \& diet foods-retail \\
\hline & & 549902 & Spices \\
\hline & & 549903 & Water companies-bottled, bulk, etc \\
\hline & & 549904 & Vitamins \\
\hline & & 549905 & Weight control preparation \\
\hline & & 549906 & Salt \\
\hline & & 549907 & Poultry-retail \\
\hline & & 549908 & Food supplements \\
\hline & & 549909 & Foods-natural \\
\hline & & 549910 & Food specialties-retail \\
\hline & & 549911 & Game birds venison etc \\
\hline & & 549912 & Kosher foods \\
\hline & & 549913 & Herbs \\
\hline & & 549914 & Eggs-retail \\
\hline & & 549915 & Coffee $\&$ tea \\
\hline & & 549916 & Oriental food products \\
\hline & & 549917 & Chinese food products \\
\hline & & 549918 & Oriental goods \\
\hline & & 549919 & Japanese food products \\
\hline & & 549920 & Gourmet shops \\
\hline & & 549921 & Imported foods \\
\hline & & 549922 & Coffee roasting $\&$ handling equipment \\
\hline & & 549923 & Korean foods \\
\hline & & 549924 & Seeds-chinese preserved \\
\hline & & 549925 & Distilled water \\
\hline & & 549926 & Hawaiian foods \\
\hline & & 549927 & Mexican \& latin american food products \\
\hline & & 549928 & Dietetic food products \\
\hline & & 549929 & Coconut products \\
\hline & & 549930 & British food products \\
\hline & & 549931 & Meat tenderizing preparations \\
\hline
\end{tabular}




\begin{tabular}{|c|c|c|c|}
\hline Category & SIC & SIC EXT & SIC Title \\
\hline & & 549932 & Soyfoods \\
\hline & & 549933 & Vegetable juices \\
\hline & & 549934 & Vitamins-raw materials \\
\hline & & 549935 & Organic foods \& services \\
\hline & & 549936 & Nutrients \\
\hline & & 549937 & Vietnamese foods \\
\hline & & 549938 & Espresso \& espresso bars \\
\hline & & 549939 & Ukrainian foods \\
\hline & & 549940 & Low carb foods \& programs \\
\hline & & 549941 & Thai food \\
\hline & & 549942 & Beach service \\
\hline & & 549943 & Awareness products \\
\hline & & 549944 & Fitness supplements \\
\hline & & 549945 & Halal foods \\
\hline & & 549946 & Native american foods \\
\hline & & 549947 & Caribbean foods \\
\hline & & 549999 & Miscellaneous food stores \\
\hline & & 54990000 & Miscellaneous food stores \\
\hline & & 54990100 & Health and dietetic food stores \\
\hline & & 54990101 & Dietetic foods \\
\hline & & 54990102 & Health foods \\
\hline & & 54990103 & Vitamin food stores \\
\hline & & 54990200 & Beverage stores \\
\hline & & 54990201 & Coffee \\
\hline & & 54990202 & Juices, fruit or vegetable \\
\hline & & 54990203 & Soft drinks \\
\hline & & 54990204 & Tea \\
\hline & & 54990205 & Water: distilled mineral or spring \\
\hline & & 54999900 & Miscellaneous food stores, (NEC) \\
\hline & & 54999901 & Dried fruit \\
\hline & & 54999902 & Eggs and poultry \\
\hline & & 54999903 & Food gift baskets \\
\hline & & 54999904 & Gourmet food stores \\
\hline & & 54999905 & Spices and herbs \\
\hline Restaurants (this includes all eating places) & 5812 & & Eating places \\
\hline & & 581201 & Luaus \\
\hline & & 581202 & Greek food products \\
\hline & & 581203 & Ice cream parlors \\
\hline & & 581204 & Wedding cakes \\
\hline & & 581205 & Hamburger $\&$ hot dog stands \\
\hline & & 581206 & Foods-carry out \\
\hline & & 581207 & Foods-institutional \\
\hline & & 581208 & Restaurants \\
\hline & & 581209 & Delicatessens \\
\hline & & 581210 & Commissary contractors \\
\hline & & 581211 & Chicken dinners \\
\hline & & 581212 & Caterers \\
\hline & & 581213 & Cafeterias \\
\hline & & 581214 & Cafes \\
\hline
\end{tabular}




\begin{tabular}{|c|c|c|c|}
\hline Category & SIC & SIC EXT & SIC Title \\
\hline & & 581215 & Box lunches \\
\hline & & 581216 & Banquets-arranged \\
\hline & & 581217 & Appetizers \& snacks etc \\
\hline & & 581218 & Soda fountain shops \\
\hline & & 581219 & Sandwiches \\
\hline & & 581220 & Restaurant management \\
\hline & & 581221 & Refreshment stands \\
\hline & & 581222 & Pizza \\
\hline & & 581223 & Banquet rooms \\
\hline & & 581224 & Barbecue \\
\hline & & 581225 & Beverages-non-alcoholic-retail \\
\hline & & 581226 & Theatres-dinner \\
\hline & & 581227 & Italian food products \\
\hline & & 581228 & Coffee shops \\
\hline & & 581229 & Deli-bakery \\
\hline & & 581230 & Restaurants-foods delivery \\
\hline & & 581231 & Food service-industrial \\
\hline & & 581232 & Chow mein \& chop suey \\
\hline & & 581233 & Jewish foods \\
\hline & & 581234 & Reception centers \\
\hline & & 581236 & Tea rooms \\
\hline & & 581237 & Dessert preparations \\
\hline & & 581238 & Cafeterias-industrial-operators \\
\hline & & 581239 & Catering-kosher \\
\hline & & 581240 & Chuck wagon dinners \\
\hline & & 581241 & Milk bars \\
\hline & & 581242 & Mobile concessions \\
\hline & & 581243 & Luncheonette food supply \\
\hline & & 581244 & Oyster bars \\
\hline & & 581245 & Escargots \\
\hline & & 581246 & Chili parlors \\
\hline & & 581248 & Juice bars \\
\hline & & 581249 & Restaurants-reservations \\
\hline & & 581250 & Wedding rehearsal dinners-restaurants \\
\hline & & 581251 & Restaurants-family dining \\
\hline & & 581252 & Cajun products \\
\hline & & 581253 & Meal preparation services \\
\hline & & 581254 & Restaurants-cyber cafes \\
\hline & & 581255 & Hookah bars \& lounges \\
\hline & & 58120000 & Eating places \\
\hline & & 58120100 & Ethnic food restaurants \\
\hline & & 58120101 & American restaurant \\
\hline & & 58120102 & Cajun restaurant \\
\hline & & 58120103 & Chinese restaurant \\
\hline & & 58120104 & French restaurant \\
\hline & & 58120105 & German restaurant \\
\hline & & 58120106 & Greek restaurant \\
\hline & & 58120107 & Indian/Pakistan restaurant \\
\hline & & 58120108 & Italian restaurant \\
\hline
\end{tabular}




\begin{tabular}{|c|c|c|c|}
\hline Category & SIC & SIC EXT & SIC Title \\
\hline & & 58120109 & Japanese restaurant \\
\hline & & 58120110 & Korean restaurant \\
\hline & & 58120111 & Lebanese restaurant \\
\hline & & 58120112 & Mexican restaurant \\
\hline & & 58120113 & Spanish restaurant \\
\hline & & 58120114 & Sushi bar \\
\hline & & 58120115 & Thai restaurant \\
\hline & & 58120116 & Vietnamese restaurant \\
\hline & & 58120117 & Pakistani restaurant \\
\hline & & 58120200 & Ice cream, soft drink and soda fountain stands \\
\hline & & 58120201 & Concessionaire \\
\hline & & 58120202 & Frozen yogurt stand \\
\hline & & 58120203 & Ice cream stands or dairy bars \\
\hline & & 58120204 & Snow cone stand \\
\hline & & 58120205 & Soda fountain \\
\hline & & 58120206 & Soft drink stand \\
\hline & & 58120300 & Fast food restaurants and stands \\
\hline & & 58120301 & Box lunch stand \\
\hline & & 58120302 & Carry-out only (except pizza) restaurant \\
\hline & & 58120303 & Chili stand \\
\hline & & 58120304 & Coffee shop \\
\hline & & 58120305 & Delicatessen (eating places) \\
\hline & & 58120306 & Drive-in restaurant \\
\hline & & 58120307 & Fast-food restaurant, chain \\
\hline & & 58120308 & Fast-food restaurant, independent \\
\hline & & 58120309 & Food bars \\
\hline & & 58120310 & Grills (eating places) \\
\hline & & 58120311 & Hamburger stand \\
\hline & & 58120312 & Hot dog stand \\
\hline & & 58120313 & Sandwiches and submarines shop \\
\hline & & 58120314 & Snack bar \\
\hline & & 58120315 & Snack shop \\
\hline & & 58120400 & Lunchrooms and cafeterias \\
\hline & & 58120401 & Automat (eating places) \\
\hline & & 58120402 & Cafeteria \\
\hline & & 58120403 & Luncheonette \\
\hline & & 58120404 & Lunchroom \\
\hline & & 58120405 & Restaurant, lunch counter \\
\hline & & 58120500 & Family restaurants \\
\hline & & 58120501 & Restaurant, family: chain \\
\hline & & 58120502 & Restaurant, family: independent \\
\hline & & 58120600 & Pizza restaurants \\
\hline & & 58120601 & Pizzeria, chain \\
\hline & & 58120602 & Pizzeria, independent \\
\hline & & 58120700 & Seafood restaurants \\
\hline & & 58120701 & Oyster bar \\
\hline & & 58120702 & Seafood shack \\
\hline & & 58120800 & Steak and barbecue restaurants \\
\hline & & 58120801 & Barbecue restaurant \\
\hline
\end{tabular}




\begin{tabular}{|c|c|c|c|}
\hline Category & SIC & SIC EXT & SIC Title \\
\hline & & 58120802 & Steak restaurant \\
\hline & & 58129900 & Eating places, (NEC) \\
\hline & & 58129901 & Buffet (eating places) \\
\hline & & 58129902 & Cafe \\
\hline & & 58129903 & Caterers \\
\hline & & 58129904 & Chicken restaurant \\
\hline & & 58129905 & Commissary restaurant \\
\hline & & 58129906 & Contract food services \\
\hline & & 58129907 & Diner \\
\hline & & 58129908 & Dinner theater \\
\hline & & 58129909 & Health food restaurant \\
\hline \multirow[t]{19}{*}{ Pharmacies and Drug Stores } & 5912 & & Drug Stores and Proprietary Stores \\
\hline & & 591201 & Medicines-patent \& proprietary \\
\hline & & 591202 & Health care products \\
\hline & & 591203 & First aid supplies \\
\hline & & 591204 & Elastic stockings \\
\hline & & 591205 & Pharmacies \\
\hline & & 591206 & Toilet articles \\
\hline & & 591207 & Pharmaceutical consultants \\
\hline & & 591208 & Razor sharpeners \& stropper \\
\hline & & 591209 & Allergy resistant products \\
\hline & & 591210 & Convalescent supplies \\
\hline & & 591211 & Drugs-crude \\
\hline & & 591212 & Homeopathic remedies \\
\hline & & 591213 & Sun tan supplies \\
\hline & & 591214 & Compounding \\
\hline & & 59120000 & Drug stores and proprietary stores \\
\hline & & 59129900 & Drug stores and proprietary stores, (NEC) \\
\hline & & 59129901 & Drug stores \\
\hline & & 59129902 & Proprietary (non-prescription medicine) stores \\
\hline
\end{tabular}

WHLS = wholesale; NEC $=$ not elsewhere classified. 
Table B. Various establishments and their primary SIC classifications for InfoUSA and D\&B.

\begin{tabular}{|c|c|c|c|c|c|}
\hline $\begin{array}{l}\text { InfoUSA } \\
\text { Company Name }\end{array}$ & $\begin{array}{l}\text { D\&B } \\
\text { Company Name }\end{array}$ & $\begin{array}{l}\text { D\&B } \\
\text { Trade Name }\end{array}$ & $\begin{array}{l}\text { InfoUSA } \\
\text { Primary } \\
\text { SIC code }\end{array}$ & $\begin{array}{l}\text { D\&B } \\
\text { Primary } \\
\text { SIC code }\end{array}$ & $\begin{array}{l}\text { Final Category for } \\
\text { Primary SIC code } \\
\text { (based on InfoUSA) }\end{array}$ \\
\hline Pop \& Beer For Less & Mckees Rocks Pop \& Beer For Le & Pop \& Beer 4 Less & 518101 & 5499 & OffSiteAlc \\
\hline Salute Distributing Inc & Salute Distributing Inc & & 518101 & 5499 & OffSiteAlc \\
\hline Ziegler's Uncommon Market & Zieglers Uncommon Market & & 514905 & 5499 & Wholesale \\
\hline Chips & Chips Inc & Value Added Foods & 514101 & 5411 & Wholesale \\
\hline Schwan's Sales Enterprises & Schwan Food Company & & 514101 & 5411 & Wholesale \\
\hline Louis Greenwald Inc & Greenwald Louis Incorporated & Bells Market & 514704 & 5411 & Wholesale \\
\hline Schwebel Baking Co & Schwebel Baking Co & & 514902 & 5461 & Wholesale \\
\hline Fortunes International Tees & Fortunes International Tees & & 514905 & 5499 & Wholesale \\
\hline Coffee Tree Roasters & Coffee Tree Roasters Corp & Warehouse & 514905 & 5499 & Wholesale \\
\hline Asian Foods & Asian Foods Inc & & 514105 & 5411 & Wholesale \\
\hline Guy's Place Bakery & Meaj Inc & Guys Place Bakery & 514902 & 5461 & Wholesale \\
\hline Mediterra Bakehouse & Mediterra Bakehouse & & 514902 & 5461 & Wholesale \\
\hline Old Vienna Baking Co & Feigs Bakery Inc & $\begin{array}{l}\text { Old Vienna Baking } \\
\text { Company }\end{array}$ & 514902 & 5461 & Wholesale \\
\hline Herky's Food Products & Herkys Food Products Inc & & 514101 & 5421 & Wholesale \\
\hline Kramer Brothers Produce Co & Kramer Brothers Produce Co & & 514801 & 5431 & Wholesale \\
\hline Folino Brothers & Folino Brothers Produce & Folino Bros & 514801 & 5421 & Wholesale \\
\hline Nickles Bakery Inc & Nickles Alfred Bakery Inc & Nickles Bakery & 514902 & 5461 & Wholesale \\
\hline Bruegger's Bagels Bakery & Brueggers Bagels & Brueggers Bagels & 514902 & 5461 & Wholesale \\
\hline O K Grocery & Giant Eagle Inc & $\begin{array}{l}\text { Giant Eagle/O K } \\
\text { Grocery }\end{array}$ & 514105 & 5411 & Wholesale \\
\hline Tristate Petroleum Inc & Exxon Tristate Petroleum & $\begin{array}{l}\text { Monroeville } \\
\text { Exxon Shop }\end{array}$ & 554101 & 5411 & Gas \\
\hline Buy 'n Fly & Mon Valley Petroleum Inc & Buy N Fly & 554101 & 5411 & Gas \\
\hline Katie’s Korner & Katies Korner & & 554101 & 5411 & Gas \\
\hline T J's Deli Mart & Kehm Oil Company & T Js Deli & 554101 & 5411 & Gas \\
\hline Renaissance Deli Provision & Renaissance Deli Provision & & 581209 & 5411 & Restaurant \\
\hline Dairy Queen & Dairy Queen Grt Southern Shop & Dairy Queen & 581203 & 5451 & Restaurant \\
\hline Rythm House Cafe & Rythm House Cafe & & 581206 & 5411 & Restaurant \\
\hline North Shore Delicatessen & North Shore Deli & & 581209 & 5411 & Restaurant \\
\hline Castellano's Deli & Castellanos Deli Inc & & 581208 & 5411 & Restaurant \\
\hline Billy's Troy Hill Bistro & Troy Hill Deli & & 581208 & 5411 & Restaurant \\
\hline Clairton's Fish \& More & Clairtons Fish \& More & & 581208 & 5421 & Restaurant \\
\hline Katerbean & 1106 South Braddock Ave Inc & Katerbean & 581228 & 5499 & Restaurant \\
\hline Rosebud Deli & Rosebud Deli Inc & $\begin{array}{l}\text { Rosebud Deli } \\
\text { Liberty Inc }\end{array}$ & 581209 & 5411 & Restaurant \\
\hline Millie's Italian Deli & Millies Italian Deli & & 581209 & 5411 & Restaurant \\
\hline Au Bon Pain & A B P Corporation & Au Bon Pain & 581208 & 5461 & Restaurant \\
\hline 6th Ave Cafe \& Deli & 6th Ave Cafe \& Deli Inc & & 581208 & 5411 & Restaurant \\
\hline Coffee A La Cart & Coffee A La Cart Inc & $\begin{array}{l}\text { Cool Beans } \\
\text { Coffee Co }\end{array}$ & 581228 & 5499 & Restaurant \\
\hline Isaly Co & Isalys Store 170 & Isaly & 581209 & 5411 & Restaurant \\
\hline Deli Junction & Deli Junction LLC & & 581212 & 5411 & Restaurant \\
\hline Brown Bag Deli & Brown Bag Inc & & 581209 & 5411 & Restaurant \\
\hline Vento's Pizza & Vento Albert P & Ventos Dairy Delite & 581222 & 5451 & Restaurant \\
\hline Grace Market & Grace Market & & 581209 & 5411 & Restaurant \\
\hline Valentina's Pizzeria \& Deli & Valentinas Pizzeria And Deli & & 581209 & 5411 & Restaurant \\
\hline
\end{tabular}




\begin{tabular}{|c|c|c|c|c|c|}
\hline $\begin{array}{l}\text { InfoUSA } \\
\text { Company Name }\end{array}$ & $\begin{array}{l}\text { D\&B } \\
\text { Company Name }\end{array}$ & $\begin{array}{l}\text { D\&B } \\
\text { Trade Name }\end{array}$ & $\begin{array}{l}\text { InfoUSA } \\
\text { Primary } \\
\text { SIC code }\end{array}$ & $\begin{array}{l}\text { D\&B } \\
\text { Primary } \\
\text { SIC code }\end{array}$ & $\begin{array}{l}\text { Final Category for } \\
\text { Primary SIC code } \\
\text { (based on InfoUSA) }\end{array}$ \\
\hline Cappo's Pizza \& 5 Points Deli & Cappos Pizza \& Five Point Deli & $\begin{array}{l}\text { Cappos Pizza \& } 5 \\
\text { Point Deli }\end{array}$ & 581208 & 5411 & Restaurant \\
\hline Bruster's Old Fashioned Ice & Brusters Old Fshiond Ice Crea & & 581203 & 5451 & Restaurant \\
\hline Dairy Queen & Dairy Queen Of Northern Pike & Dairy Queen & 581203 & 5451 & Restaurant \\
\hline Carson Street Deli & Carson Street Deli & & 581212 & 5411 & Restaurant \\
\hline Panera Bread & Covelli Enterprises Inc & Panera Bread & 581208 & 5461 & Restaurant \\
\hline Speedy Gourmet & Speedy Gourmet Inc & & 581209 & 5411 & Restaurant \\
\hline Panera Bread & Covelli Enterprises Inc & Panera Bread & 581208 & 5461 & Restaurant \\
\hline Pittsburgh Presse Deli & Pittsburgh Presse Deli Holding & & 581209 & 5411 & Restaurant \\
\hline Sam's Market & Sams Market & & 581208 & 5411 & Restaurant \\
\hline La Prima Espresso Co & La Prima Expresso Co & La Prima Espresso & 581208 & 5499 & Restaurant \\
\hline Dairy Queen & Dairy Queen Of South Side & Dairy Queen & 581203 & 5451 & Restaurant \\
\hline Folino's Deli & Folinos Deli & & 581209 & 5411 & Restaurant \\
\hline Bruster's Old Fashioned Ice & Stacy Jos Ice Cream Inc & Brewsters & 581203 & 5451 & Restaurant \\
\hline Cafe Venice Pizzeria \& Deli & Cafe Venice Pizzeria \& Deli & & 581208 & 5411 & Restaurant \\
\hline Victoria's Deli & Victorias Deli & & 581209 & 5411 & Restaurant \\
\hline Sal's Scotch Bottom Deli & Sals Scotch Bottom Deli LLC & & 581209 & 5411 & Restaurant \\
\hline Kazansky's Delicatessen & Bennett Brothers Inc & Kazanskys Delicatessen & 581209 & 5411 & Restaurant \\
\hline 61 C Cafe & 61 C Cafe Inc & & 581228 & 5499 & Restaurant \\
\hline Moses Quality Market & Moses Quality Market & & 581209 & 5411 & Restaurant \\
\hline Panera Bread & Covelli Enterprises Inc & Panera Bread & 581208 & 5461 & Restaurant \\
\hline Najanick \& Ross Food \& Snack & Najanick \& Ross Food \& Snack S & & 581209 & 5411 & Restaurant \\
\hline Scoops On Beverly & Scoops On Beverly & & 581203 & 5451 & Restaurant \\
\hline Panera Bread & Covelli Enterprises Inc & & 581208 & 5461 & Restaurant \\
\hline New Way Gourmet Deli \& Rstrnt & New Way Gorment Food \& Deli & New Way Gourmet & 581208 & 5411 & Restaurant \\
\hline Webster Hall Deli Inc & Webster Hall Deli Inc & & 581209 & 5411 & Restaurant \\
\hline La Prima Espresso Co & La Prima Expresso Co & Cafe Zio & 581208 & 5499 & Restaurant \\
\hline Salim's Middle Eastern Food & Salims Middle Eastern Food Co & & 581209 & 5411 & Restaurant \\
\hline Krispy Kreme Doughnuts & Metz \& Associates Ltd & $\begin{array}{l}\text { Century III Krispy } \\
\text { Kreme } 1101\end{array}$ & 581208 & 5461 & Restaurant \\
\hline Kribels Bakery & Kribels Bakery Inc & Kribel Bakery & 581208 & 5461 & Restaurant \\
\hline Gloria Jean's Gourmet Coffees & Dan-Cam Inc & $\begin{array}{l}\text { Gloria Jeans } \\
\text { Gourmet Coffee }\end{array}$ & 581228 & 5499 & Restaurant \\
\hline American Body Building-Pa W & American Body Building & & 581225 & 5499 & Restaurant \\
\hline Panera Bread & Covelli Enterprises Inc & & 581208 & 5461 & Restaurant \\
\hline Rita's Italian Ice & Ritas Italian Ices & Ritas Italian Ice & 581203 & 5451 & Restaurant \\
\hline Pino's Mercato & Pinos Mercato Inc & & 581212 & 5411 & Restaurant \\
\hline Sandy's Deli & Sandys Delicatessen Inc & & 581209 & 5411 & Restaurant \\
\hline Sharon's Deli Mart & Sharon Deli Mart & & 581209 & 5411 & Restaurant \\
\hline Rita's Italian Ice & Ritas Italian Ice & Ritas Italian Ice & 581203 & 5451 & Restaurant \\
\hline Martin's Fruit Basket & Martins Fruit Baskets & Martins Cafe-Deli & 581209 & 5431 & Restaurant \\
\hline Liberty Dairy Store & Liberty Dairy Store & & 581209 & 5411 & Restaurant \\
\hline Alfred's Deli Plus & Alfreds Deli Plus & & 581209 & 5411 & Restaurant \\
\hline Nirvana Deli & Nirvana Deli & & 581208 & 5411 & Restaurant \\
\hline Campus Deli & Campus Deli & & 581208 & 5411 & Restaurant \\
\hline Panera Bread Cafe' & Covelli Enterprises Inc & & 581214 & 5461 & Restaurant \\
\hline Panera Bread & Covelli Enterprises Inc & & 581208 & 5461 & Restaurant \\
\hline
\end{tabular}




\begin{tabular}{|c|c|c|c|c|c|}
\hline $\begin{array}{l}\text { InfoUSA } \\
\text { Company Name }\end{array}$ & $\begin{array}{l}\text { D\&B } \\
\text { Company Name }\end{array}$ & $\begin{array}{l}\text { D\&B } \\
\text { Trade Name }\end{array}$ & $\begin{array}{l}\text { InfoUSA } \\
\text { Primary } \\
\text { SIC code }\end{array}$ & $\begin{array}{l}\text { D\&B } \\
\text { Primary } \\
\text { SIC code }\end{array}$ & $\begin{array}{l}\text { Final Category for } \\
\text { Primary SIC code } \\
\text { (based on InfoUSA) }\end{array}$ \\
\hline Produce Plus & Produce Plus & & 581209 & 5431 & Restaurant \\
\hline Panera Bread & Covelli Enterprises Inc & & 581208 & 5461 & Restaurant \\
\hline Green Chef & Green Chef & & 581209 & 5411 & Restaurant \\
\hline Community Supermarket & Community Supermarket Inc & & 581209 & 5411 & Restaurant \\
\hline Panera Bread & Covelli Enterprises Inc & Panera Bread & 581208 & 5461 & Restaurant \\
\hline Hot Tops Cake N Bake Pizza & Cal-A-Donut Inc & & 581208 & 5461 & Restaurant \\
\hline Smitys Market \& Deli & Smitys Deli \& Market & Smittys Market \& Deli & 581209 & 5411 & Restaurant \\
\hline Steamers Expresso Cafe Ltd & Steamers Espresso Cafe Ltd & & 581228 & 5499 & Restaurant \\
\hline Joe's Water Ice & Joes Water Ice & & 581203 & 5451 & Restaurant \\
\hline Great Valley Restaurant & Matco Foods Inc & Great Valley Foodland & 581208 & 5411 & Restaurant \\
\hline Uncommon Market & Uncommon Market Inc & & 581212 & 5499 & Restaurant \\
\hline Bethel Bakery & Bethel Bakery Inc & & 581208 & 5461 & Restaurant \\
\hline Au Bon Pain Co & A B P Corporation & Au Bon Pain & 581208 & 5461 & Restaurant \\
\hline Family Deli & Family Foods Inc & Family Deli & 581209 & 5411 & Restaurant \\
\hline Panera Bread & Covelli Enterprises Inc & & 581208 & 5461 & Restaurant \\
\hline Marianne's Cool Treats & Mariannes Cool Treats & & 581203 & 5451 & Restaurant \\
\hline Gloria Jeans Gourmet Coffee & Gloria Jeans Gourmet Cof Beans & $\begin{array}{l}\text { Gloria Jeans } \\
\text { Gourmet Coffee }\end{array}$ & 581228 & 5499 & Restaurant \\
\hline Frisch's Carrick Poultry & Carrick Poultry & Carrick Poultry Market & 581212 & 5499 & Restaurant \\
\hline Main Street Deli & Main Street Deli & & 581209 & 5411 & Restaurant \\
\hline Castellano Deli Mart & Zeiglers Deli Mart & & 581209 & 5411 & Restaurant \\
\hline Jack's Pizza \& Hoagies & Jacks Pizza \& Hoagies & & 581208 & 5411 & Restaurant \\
\hline Dairy Queen & Dairy Qeen Brazier Natrona Hts & Dairy Queen & 581203 & 5451 & Restaurant \\
\hline Starr Road Mushroom Market & Starr Road Mushroom Market & & 581209 & 5411 & Restaurant \\
\hline Glen's Frozen Custard & Glens Frozen Custard & & 581203 & 5451 & Restaurant \\
\hline Baskin-Robbins Ice Cream & George Robert Inc & Donut Connection & 581203 & 5461 & Restaurant \\
\hline Panera Bread & Covelli Enterprises Inc & & 581208 & 5461 & Restaurant \\
\hline Boardwalk Custard & Boardwalk Custard & & 581203 & 5451 & Restaurant \\
\hline Wexford Post Office Deli & Wexford Po Deli \& Catrg & $\begin{array}{l}\text { Wexford Post } \\
\text { Office Deli }\end{array}$ & 581209 & 5411 & Restaurant \\
\hline Giant Eagle & Giant Eagle & $\begin{array}{l}\text { Edgewood Giant } \\
\text { Eagle }\end{array}$ & 591205 & 5411 & Pharmacy \\
\hline Giant Eagle & Giant Eagle 6379 Inc & Giant Eagle & 591205 & 5411 & Pharmacy \\
\hline Shop 'n Save Pharmacy & Fresh Foods Inc & $\begin{array}{l}\text { Shop N Save } \\
\text { Mount Lebanon }\end{array}$ & 591205 & 5411 & Pharmacy \\
\hline Giant Eagle & Giant Eagle Inc & Giant Eagle & 591205 & 5411 & Pharmacy \\
\hline Giant Eagle Pharmacy Dept & Giant Eagle Inc & Giant Eagle & 591205 & 5411 & Pharmacy \\
\hline
\end{tabular}

